\section{Entre tapas e beijos: A favela turística na perspectiva de seus moradores}

Bianca Freire-Medeiros ${ }^{2}$

Resumo: Parte de um projeto de pesquisa mais amplo sobre a pobreza turística em diferentes partes do mundo, este artigo objetiva investigar as opiniões dos moradores sobre a conversão de seu lugar de moradia em destino turístico. Tem como referente empírico a Rocinha, onde passeios ocorrem regularmente desde inícios da década de 1990, com uma média de 3.500 turistas por mês. A metodologia envolve diferentes estratégias de pesquisa: entrevistas em profundidade com informantes qualificados, observações de campo e questionário semiestruturado aplicado junto a 175 moradores. Conclui que, entre a aprovação irrestrita e a desaprovação incondicional das práticas turísticas por parte dos moradores, há uma série de nuances que devem ser cuidadosamente examinadas.

Palavras-chave: Turismo; favela; favelados; pobreza; Rio de Janeiro.

\section{Introdução}

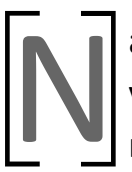
a década de 1970, enquanto as agências internacionais de desenvolvimento apostavam no turismo como solução para os problemas econômicos das nações periféricas, os cientistas sociais examinavam criticamente seu impacto nas comunidades receptoras, apontando para seus efeitos nefastos: dependência econômica, corrosão de valores, alteração de práticas culturais, degradação ambiental. O turismo era tomado como sinônimo de exploração e aculturação, epítome do poder devastador da sociedade de consumo e ameaça ao equilíbrio ambiental das comunidades hospedeiras.

Desde então, muito já se relativizou e hoje há, entre os estudiosos do turismo, uma preocupação em entender de forma menos balizada a complexa rede de relações de poder e de intimidade que são formadas por Estados, companhias multinacionais, empresas privadas, promotores e viajantes envolvidos na movimentação global que o turismo engendra (Barretto, 2003;
Recebimento:

22.11.2009

Aprovado:

15.01.2010

1. Este artigo deriva das reflexões contidas nos projetos de pesquisa "Touring poverty in Buenos Aires, Johannesburg and Rio de Janeiro" (financiado pela Foundation for Urban and Regional Studies -FURS) e "Para ver os pobres: A construção da favela carioca como destino turístico" (financiado pelo (NPq). Reproduz-se aqui, de maneira abreviada, boa parte dos argumentos apresentados no livro que sintetiza os principais resultados da pesquisa (FreireMedeiros, 2009).

\section{Mestre em} Sociologia (luperj) e doutora em história e teoria da arte e da arquitetura (Binghamton University, Suny). Professora do CPDOC/FGV, bolsista de Produtividade do CNPq e autora de Gringo na Laje: Produção, circulação e consumo da favela turística (FGV Editora, 2009).

E-mail:

freiremedeiros@fgv.br 
3. Participaram em diferentes etapas: Alexandre A. de Magalhães, André Salata, Andréia C. Santos, Fernanda Nunes, Livia Campello, Mariana Mendonça, Juliana Farias, Lidia Medeiros e Palloma Menezes. A todos agradeço pelo entusiasmo e colaboração.
Urry, 2007). Parece haver um consenso de que, por meio do turismo, amizades e inimizades são geradas, territórios e comunidades são moldados e legitimados, culturas são hierarquizadas, reconhecidas e renegociadas. No entanto, poucos são os trabalhos que examinam como essas relações de confiança e desconfiança, aproximação e indiferença são formadas e mantidas no plano empírico. A literatura antropológica, por exemplo, tem privilegiado comunidades de certo modo fechadas ou isoladas na tentativa de identificar as alterações em seus padrões culturais a partir do contato com os turistas. Os sociólogos e turismólogos, por sua vez, costumam deter-se nos aspectos mais estruturais e, muitas vezes, as sutilezas das relações cotidianas acabam por se perder.

Parte de um projeto de pesquisa mais amplo sobre a pobreza turística uma pobreza emoldurada, anunciada, vendida e consumida com um valor monetário acordado entre promotores e consumidores em diferentes partes do mundo ${ }^{3}$-, este artigo toma a Rocinha, favela turística por excelência como referente empírico e busca identificar as diferentes reações de seus habitantes à conversão daquele espaço em atração turística. Será que eles se sentem e se posicionam apenas como objetos do olhar estrangeiro ou também como personagens ativos de um encontro entre diferentes? Veem o turismo como uma possibilidade de desenvolvimento econômico ou como mais uma forma de exploração? Que nuances constroem e deixam transparecer entre a aprovação irrestrita e a desaprovação incondicional?

Para responder a esse conjunto de questões, além das observações feitas durante o trabalho de campo e das muitas conversas informais que já configuravam a nossa rotina de pesquisa, entre os meses de novembro de 2006 e abril de 2007 nossa equipe realizou um total de 175 entrevistas semiestruturadas com residentes de diferentes partes da Rocinha. Deixávamos claro aos entrevistados que não tínhamos qualquer relação com as agências e que não haveria identificação nominal nos questionários.

Começávamos com perguntas contextuais: quando ele(a) começara a perceber a presença dos turistas na Rocinha, de que maneira essa presença alterava o dia a dia na localidade, se ele(a) já havia tido contato com algum turista ou com o pessoal das agências. Passávamos a questões opinativas sobre a presença dos turistas e pedíamos que especulassem sobre as possíveis motivações que levariam os estrangeiros a visitar a favela. Em seguida, os entrevistados eram provocados a se colocar como guias e promotores do turismo: "se você pudesse fazer o passeio com os turistas, como seria?"; 
"quanto você acha que poderia cobrar por esse passeio?"; "se os turistas quisessem levar alguma lembrança da Rocinha para colocar na casa deles ou dar para algum amigo, o que você sugeriria?"

Em relação à fotografia, perguntávamos não apenas se ele(a), algum membro da família ou a própria casa já haviam sido fotografados por algum turista e qual fora (ou teria sido) sua reação, mas também o que ele(a) diria para os turistas fotografarem. Os entrevistados eram colocados na posição de turistas quando indagávamos se tinham o hábito de viajar nas férias, para onde, em que lugar se hospedavam, se costumavam tirar fotografias e comprar suvenires. Encerrávamos perguntando o que era esperado do turismo na Rocinha e o que, em sua opinião, havia de melhor e de pior na localidade - não em relação ao turismo, mas em termos gerais.

No mais das vezes, a recepção dos nossos entrevistados - moradores com idade entre 18 e 70 anos, pertencentes às chamadas classes D e E e majoritariamente nascidos no estado do Rio de Janeiro, participantes ou não em atividades comunitárias - foi bastante positiva e permitiu construir um panorama extremamente interessante da relação entre "hosts and guests" na favela turística. Antes, porém, de iniciarmos nossa conversa com os moradores, é preciso entender, ainda que rapidamente, os princípios de funcionamento desse destino turístico peculiar.

\section{A favela carioca como destino turístico}

Ao seguir uma tendência internacional de conversão de territórios pobres e segregados em atração turística, várias favelas cariocas vêm, com maior ou menor sucesso, buscando desenvolver seu potencial turístico (FreireMedeiros, 2007). Apenas a Rocinha, no entanto, possui um mercado turístico consolidado há mais de uma década. ${ }^{4}$ Em conjunto, as agências que ali atuam (sete com registro na Riotur) atendem a uma média de 3.500 turistas por mês, os quais se dispõem a pagar algo em torno de U\$ 35,00 por um passeio que dura entre três e quatro horas.

Os passeios, dependendo da agência escolhida, podem ser feitos de jeep ou moto, de van ou a pé. Em geral, incluem três paradas: a primeira no principal ponto de venda de suvenires, localizado na Rua 1, onde os visitantes podem adquirir variados produtos by Rocinha (camisetas, quadros, bolsas, bijuterias etc.) comercializados por oito moradores que hoje têm nessa atividade sua principal fonte de renda. ${ }^{5}$ A segunda, no Largo do Boiadeiro, para que os

\footnotetext{
4. Os donos das agências concordam que o marco inicial do mercado turístico na Rocinha remete ao episódio da Eco92 (Rio Conference on Environment and Sustainable Development). Não há, entretanto, qualquer consenso sobre quem de fato teria inaugurado o mercado turístico na localidade. Contendas acirradas pela "paternidade" da ideia marcam, ainda hoje, o convívio entre as agências.

5. Sobre a dinâmica de produção, venda e consumo de suvenires na Rocinha, cf. FreireMedeiros et alii, 2008a.
} 
visitantes caminhem em meio a barracas de produtos nordestinos; e a terceira, em algum terraço que é utilizado como uma espécie de mirante. Esse "momento laje" é, sem dúvida, um dos mais apreciados pelos turistas: com o mar de casas a seus pés, eles podem confrontar a favela com seu entorno, as casas mal alinhadas com os caríssimos edifícios à beira do mar.

A maioria das agências antecipa a experiência do tour em seus websites, descrevendo os passeios e postando comentários positivos de seus clientes. As imagens escolhidas pelas diferentes agências para ilustrar seus sites remetem a temas comuns: a deslumbrante vista da favela, as edificações desalinhadas, moradores sorridentes (sobretudo crianças) interagindo com turistas igualmente satisfeitos. O turista em potencial é incentivado a levar sua máquina fotográfica e sua filmadora sem medo - há, de fato, uma forte ênfase na questão da segurança, que estaria sendo totalmente garantida pelas agências. Reforça-se ainda a ideia de que o turista é sempre benvindo pelos moradores e que os tours são fonte de geração de renda para a localidade.

Há variações nos discursos que cada agência prepara e com os quais capacita seus guias, mas, de maneira geral, a Rocinha é tomada como paradigma do que sejam as favelas cariocas, as quais são descritas nos passeios como territórios marginais à cidade formal, cuja origem remete à negligência do poder público e à ganância das elites locais. Os guias costumam ressaltar que, nos últimos anos, esse quadro vem sendo alterado, com a progressiva incorporação das favelas ao asfalto, sendo as obras do projeto Favela-Bairro o exemplo recorrentemente citado. São dadas, também, instruções gerais aos turistas: ignorar eventuais provocações, não interromper a passagem dos moradores nas ruazinhas estreitas e não dar esmola. São destacadas as supostas peculiaridades da favela em relação ao restante da cidade: a arquitetura ímpar, o recurso insistente ao criativo "jeitinho brasileiro" (o chamado "gato de luz", presente por toda a favela, seria o seu melhor exemplo), a espontaneidade alegre da população e sua submissão às leis do "poder paralelo". Não é incomum comentarem que, graças a essas leis violentas e arbitrárias, roubos, furtos e estupros são praticamente inexistentes na localidade.

Desde setembro de 2006, a Rocinha passou a figurar entre os pontos turísticos oficiais da cidade do Rio de Janeiro. O projeto de lei, de autoria da vereadora Lilian Sá e sancionado pelo prefeito César Maia, justificava a inclusão da favela com base em seus "diversos atrativos muito peculiares", 
entre os quais "um forte sentimento de comunidade". A iniciativa teve apoio imediato do presidente da Riotur, Rubem Medina: "A Rocinha é uma atração turística há um bom tempo. É importante que seja incluída no Guia Oficial para que as excursões, o artesanato e outros atrativos sejam mais divulgados" (Globo Online, 20.09.06). Assim que tomou posse à frente do governo do estado, Sérgio Cabral anunciou, como parte das obras do PAC na Rocinha, a transformação de residências na parte alta do morro em pousadas do tipo bed \& breakfast.

A despeito da recusa das elites - que veem, no mais das vezes, o tour em favela como uma aberração ${ }^{6}$ - agências turísticas e poder público concordam sobre a validade de se promover a Rocinha como uma das atrações turísticas da cidade. Os guias de viagem mais populares, como o Lonely Planet, não apenas listam o tour de favela entre as grandes atrações da cidade, mas sugerem que a partir dele os turistas terão de fato uma percepção mais realista da cidade. Os turistas que realizam os passeios, na maior parte dos casos, não apenas se dizem muito satisfeitos com a experiência, como a recomendam entusiasticamente (Freire-Medeiros et alii, 2008a; Freire-Medeiros et alii, 2009). Cabe indagar, então, o que os favelados - parte fundamental da trama - pensam sobre a conversão de seu local de moradia em atração turística.

\section{3. "Morador não é otário"}

"Apesar das poucas pesquisas sistematizadas a respeito" - afirma Margarita Barretto (2004) -, "as existentes demonstram que, na verdade, os habitantes dos lugares turísticos, que se beneficiam economicamente com a presença dos turistas, não estão precisamente interessados em receber os turistas como hóspedes e a realizar com eles trocas culturais, mas sim, em receber o dinheiro trazido pelos turistas." A antropóloga encerra: "Os turistas passam a ser um mal necessário. Mal porque sua presença incomoda. Necessário porque seu dinheiro faz falta." No caso do turismo na favela, nossos entrevistados apresentaram ponderações difíceis de encaixar nesse modelo. Até hoje, o turismo na Rocinha beneficia economicamente um segmento muito específico e minoritário, não promove uma distribuição efetiva de lucros e as agências de turismo raramente estabelecem qualquer diálogo com as instituições representativas da localidade (Dwek, 2004; Carter, 2005). Ainda assim, a maioria de nossos entrevistados (84\%), mesmo sem ter qualquer ganho direto e significativo com o business, vê com simpatia a presença dos turistas.

6. O Estado de São Paulo realizou, em fevereiro de 2007, uma enquete com o título de "O turismo em favelas deve ser incentivado?". Quase $80 \%$ dos leitores que se pronunciaram o fizeram com o propósito de criticar a iniciativa: causavaIhes um verdadeiro choque cognitivo a associação turismo/ favela. A ideia de promover a Rocinha ao lado de outros destinos turísticos como Corcovado e Pão de Açúcar - era vista, para dizer o mínimo, como estapafúrdia. 
É preciso levar em consideração que uma resposta classificada como "positiva" traz consigo um escopo extremamente variado de justificativas imperceptíveis ao ouvido apressado. Essas justificativas podem estar baseadas, não há dúvida, em motivações econômicas que apontam para o ganho direto - ainda que pontual - atribuído à presença dos turistas. C., caixa de supermercado de 20 anos, relatou com um sorriso cúmplice: “Uma vez minha filha estava na porta da casa da minha sogra e passou um turista que deu a ela $R \$ 50,00$. Eles ajudam assim, veem as crianças e dão dinheiro a elas".

O dinheiro sequer precisa ser ganho ou visto para funcionar como confirmação da boa vontade dos turistas: "Se eles vêm, só pode ser para ajudar", sentenciou um morador acostumado ao trânsito das agências pela porta de sua casa. Outras vezes, "tirar um dinheiro" do turista pode ser experimentado como uma maneira de subverter a assimetria da relação: "Uma colega minha tem um bar que é muito pequeno. E o turista chegou [no bar] louco de vontade de usar o vaso, então ele deu $R \$ 50,00$ só para usar o vaso! Isso eu achei maneiro! Acho engraçado eles agirem desse jeito... Eles não têm noção! Pensa só: $\mathrm{R} \$ 50,00$ só para usar o vaso!!!"

Se, muitas vezes, o interesse de ganho econômico em seu sentido mais amplo aparece como justificativa para uma valoração positiva do turismo por parte dos moradores, outras tantas vezes, porém, ser a favor do turismo significa apostar no suposto contraestigma possibilitado pela visita dos estrangeiros. Depois de verem com seus próprios olhos a favela - apostam os moradores -, os turistas seriam capazes de desmistificar a imagem violenta insistentemente reiterada pelas elites e veiculada pelos meios de comunicação, como explica a jovem D.: "As pessoas todas veem a favela de uma forma que não cabe [...]. Acho a presença deles [turistas] importante por isso. Porque eles veem, daí pode passar na televisão e eles falarem: 'eu vi e não é bem assim.' Por mais que seja uma favela, tem coisas de qualidade, tem coisas que interessam que não é só tráfico, esse tipo de coisa, que tem dentro da favela. Tem cultura, tem pessoas de personalidade, de caráter, educadas."

A despeito de todas as suas limitações, a proximidade física entre visitantes e visitados que a prática turística na favela possibilita é vista como capaz de fazer frente ao pacote interpretativo que explica a favela a partir da "metáfora da guerra" (Leite, 2008) ou que aponta para a existência de uma inevitável cumplicidade entre moradores de favela (especialmente os mais jovens) e criminosos: "Acho superlegal isso [o turismo]. Mostra que é diferente da Rocinha que aparece na televisão, que a Rocinha não é um bicho 
de sete cabeças, por causa do tráfico e coisa assim. E os turistas estão aqui para diminuir isso, essa coisa de dizer que a Rocinha só tem tráfico... Isso é o que a gente espera deles: que quando eles voltarem ao local deles, mostrem isso, coisa boa da Rocinha e não coisa ruim" (F., 22 anos, estudante).

$\mathrm{Na}$ época da pesquisa, A. tinha 26 anos e trabalhava em um consultório odontológico. Havia poucas semanas, seu marido tinha sido atingido por uma bala perdida durante um confronto entre policiais e traficantes. Ela também aposta no potencial do turismo de colaborar na construção de um contraestigma, de uma imagem da favela que se oponha não àquela do senso comum: "A mim [a presença dos turistas] não incomoda. Até faz bem para comunidade, ajuda a tirar aquela ideia de que é um lugar violento. Eu tenho amigos que, quando falo que moro na Rocinha, dizem que não vão lá nunca, pois teria tiroteio todo dia, toda hora. Então, com o turismo tira essa impressão de que é só violência."

Nesse sentido, não causa surpresa que a maioria dos entrevistados (82\%) afirme que as áreas mais pobres não devem ser mostradas aos turistas - afinal, são as imagens da pobreza e da violência, em seu sentido mais amplo, aquelas que circulam vinculadas à favela. Quando pedimos a eles que se colocassem na posição de guias turísticos, a maioria se mostrou bastante entusiasmada em divulgar o que considerava os aspectos mais positivos da favela: a vista, o comércio, os projetos sociais, a mata e o artesanato. Muitos não querem que os aspectos negativos - barracos precários, lixo, desorganização do espaço, violência - sejam os predicados associados à Rocinha turística.

É preciso observar, porém, que os moradores não estão alheios ao fato de que, para os visitantes de maneira geral, os grandes atrativos da Rocinha como destino turístico são a pobreza e a violência, o vasto contraste entre sua realidade cotidiana e aquela dos turistas. Quando lhe perguntamos por que os turistas têm interesse em visitar a Rocinha, a balconista R., de 25 anos, respondeu aquilo que ouvimos da maior parte dos entrevistados: "A pessoa quando vem lá de fora, de outro país, tem interesse de conhecer as comunidades pobres daqui, do Rio de Janeiro e do Brasil, e ver como é que é. Porque, bem ou mal, eles [os turistas] fazem uma comparação entre a comunidade deles e a nossa. Então eles querem ver a diferença. A curiosidade deles é essa."

Há quem acredite que é importante mostrar os dois lados da moeda, como explicou a balconista M.: "Tem de mostrar a realidade da Rocinha, o cotidia- 
no, as coisas boas e as coisas ruins. Tem casas que ainda são de pau a pique, barracos de madeira... Tem de mostrar tudo, tudo. O bom e o ruim." Vale notar que, mesmo nesses casos, a intenção não parece ser desagradar o turista ou agredi-lo, mas revelar a favela em sua complexidade.

A fala de A. e seu esforço em compatibilizar os diferentes qualificativos da favela ilustram como os processos de geração da pobreza turística podem conduzir a novas formas de interpretar a identidade do local: "A Rocinha é imensa, existem muitos lugares bonitos. Perto do Laboriaux nós temos muitas cachoeiras, algumas represas, uma vista maravilhosa - de lá você pode ver a praia do Leblon, a praia de Ipanema, você vê as montanhas, vê a praia de São Conrado, toda a comunidade de cima pra baixo. Levaria para conhecerem algumas figuras antigas da comunidade e algumas casas que ainda representam a Rocinha de vinte anos atrás. As pessoas que sobem na Rocinha têm de ver tudo, para ter uma noção de como é a vida... Existe esse contraste, então é uma realidade que precisa ser revista..." (A., barbeiro, 30 anos).

"Você vai encontrar aqui três tipos de morador", explicou uma liderança comunitária da Rocinha, apresentando uma classificação referenciada pelo suposto grau de conscientização e engajamento nos assuntos coletivos. No primeiro degrau, estariam os que trabalham o dia inteiro, "descem e sobem o morro e não se importam com nada que acontece na Rocinha." No segundo degrau, os artesãos que, por sua vez, estariam subdivididos em dois grupos: os que têm "conchavo com as agências e conseguem vender seus produtos para os gringos" e os que, por não fazerem "alianças duvidosas", ficam excluídos do business. No topo estariam as lideranças locais, o único grupo realmente preocupado com a "comunidade" e, portanto, capaz de criticar o trabalho das agências. Contrariando esse modelo explicativo, o fato de participar de alguma associação, de estar mais engajado na vida associativa da favela, não parece - pelo que avaliamos a partir das entrevistas - levar a uma ponderação mais crítica do turismo ou do modus operandi das agências.

Para as lideranças comunitárias que se dispuseram a estabelecer uma interlocução com nossa equipe também não se trata de rejeitar o turismo, mas de fazer oposição à maneira como as agências em atuação na Rocinha têm explorado a localidade como destino turístico. Em uma longa entrevista que nos concedeu, assim como em declarações à imprensa, William de Oliveira, então presidente da União Pró-Melhoramentos dos Moradores da Rocinha (UPMMR), sempre procurou deixar claro que não se opunha à pre- 
sença dos turistas, mas à forma de apresentar a favela e, sobretudo, a como os lucros vêm sendo compartilhados: "Eles sobem no Cristo, pagam. Sobem no Pão de Açúcar, pagam. Sobem aqui, levam."

No verão de 2006, a UPMMR decidiu reverter esse quadro estabelecendo uma parceria com uma agência interessada em explorar o potencial turístico da Rocinha. Renê Melo, então secretário de cultura da UPMMR, nos contou que um roteiro alternativo foi desenhado para garantir um "turismo verdadeiro": visitas conduzidas por "jovens da comunidade" às casas dos moradores mais antigos, ao posto de saúde local e às áreas cujas condições de habitação são mais precárias. "Turismo verdadeiro", argumentou Renê, "é aquele em que você não mexe na história da comunidade. Tem de contar a história verdadeira; como surgiu a Rocinha, em que ano foi fundada a primeira associação [de moradores], o número de habitantes... Mas não basta só contar história. Tem de ter a participação da comunidade." Ao final do passeio, na quadra da escola de samba, o turista receberia um "diploma de cidadão honorário da Rocinha" ao lado de passistas de carnaval e jovens jogando capoeira. Esse "roteiro de dentro" - que, ironicamente, seria muito mais "encenado" do que os tours que hoje são promovidos por agentes externos -, contava com o apoio verbal do então ministro da Cultura Gilberto Gil e dos senadores Eduardo Suplicy e Saturnino Braga - este último prometera levar o projeto ao Banco Nacional de Desenvolvimento Econômico e Social (BNDES) e pleitear financiamento. Folhetos chegaram a ser impressos, mas os passeios jamais se realizaram. Segundo Renê, a agência parceira, apesar de inicialmente disposta a encaminhar em conjunto a iniciativa, se mostrou desconfortável em negociar com o grupo de moradores locais e descrente em sua capacidade de gerenciar o projeto.

Daniela Machado (2007), em sua dissertação de mestrado que tem a pequena favela de Vila Canoas, próxima à Rocinha, como referência empírica principal e esta última como contraponto, também observa que os moradores, envolvidos ou não com o turismo de favela, percebem a atividade turística na comunidade de maneira positiva. Embora partilhem da ideia de que não estão sendo criadas oportunidades de geração de renda significativa, os moradores acreditam que a presença dos turistas é capaz de provocar mudanças necessárias.

Em Vila Canoas, Machado identifica dois problemas principais com relação à maneira como o turismo vem sendo desenvolvido: o primeiro, de ordem organizacional, deve-se ao fato de os roteiros de visitação excluir delibera- 
damente certos pontos de vendas de artesanato local; o segundo, de ordem estrutural, refere-se à distribuição dos benefícios econômicos. Um ponto de destaque vai para o fato de que as pessoas mobilizadas pelo turismo em Vila Canoas não têm essa atividade como principal fonte de renda, ao contrário do que acontece na Rocinha.

Segundo a autora, em ambas as comunidades, alguns moradores veem essa forma de turismo como "invasiva" e "desqualificadora"; outros acreditam que os turistas são filantrópicos e conciliadores. Baseando-se em entrevistas com moradores das duas localidades, Machado (2007) sugere que eles não se mostram ofendidos com as atitudes preconceituosas dos turistas porque têm a ideia de que os estrangeiros podem, ao concluir o passeio, ter outra imagem da favela. Ainda que na Rocinha o discurso de "resistência" seja mais contundente e que os moradores falem em sentimentos como vergonha e desrespeito, em ambos os casos estaríamos diante de uma "posição de subalternidade social" dos moradores em relação aos turistas: "Embora um interesse diferenciado pelos valores comportamentais dos moradores possa ser visto como um esforço de 'encontro' e valorização positiva da vida em comunidade, a forma autoritária e invasiva como este se dá deixa entrever a relação desigual e assimétrica a que estamos nos referindo neste trabalho. Esta assimetria, no entanto, nem sempre é percebida pelos moradores, bastante mais preocupados com as desigualdades das relações de poder que existem no interior da própria comunidade..."

Ao incorrer em petição de princípio, Machado faz coro com os que afirmam que o turismo na favela é necessariamente um zoológico de pobre e que os favelados, se aceitam a presença estrangeira, é porque ainda não entenderam seu caráter degradante. Aqui há pelos menos duas pressuposições subjacentes: a primeira é que tanto turistas quanto favelados constituem grupos homogêneos; a segunda é que, diferente dos turistas e de nós - representantes dos segmentos esclarecidos -, os favelados são destituídos de reflexividade, da capacidade de pensar de forma crítica sobre sua própria situação, da competência de articulação interpretativa do real. Há também um argumento sobreposto: cabe a nós, elite ilustrada, defender os favelados desses turistas desalmados e voyeuristas que os veem como animais em jaulas. Talvez a dificuldade esteja em aceitarmos o quinhão que nos cabe desse latifúndio: quando os moradores da Rocinha identificam como principal característica positiva do turismo na favela a visibilidade e a produção de contraestigmas, está sendo posta uma recusa à invisibilidade e aos estigmas que nós, sociedade brasileira, ajudamos a produzir ao longo 
desses cem anos de favela. Como resumiu G., aposentada de 64 anos: "O pessoal daqui não dá a mínima para a Rocinha, mas vem gente do mundo todo ver como a Rocinha é."

"A comunidade não ignora o turista", observa um guia de turismo e morador da Rocinha. "Até tentam interagir - 'hello, man! how are you?' [risos] -, tentam até contar um pouco a sua história, mas tem a barreira da língua... Os moradores não ignoram o turista, ignoram é como a coisa toda funciona". Mas quem, entre os participantes desse cenário, de fato sabe "como a coisa toda funciona?" Pelo que pude observar ao longo da pesquisa, certamente não são os turistas, os quais desconhecem, por exemplo, que o dinheiro pago pelo passeio não é revertido diretamente para a localidade. As agências? Na opinião dos guias com quem conversamos, bem como dos vendedores de suvenires, os donos das agências, salvo raras exceções, estão preocupados com a gerência de seus negócios e nada mais. Os guias, então? Tampouco. Ainda que ocupem uma posição estratégica e detenham informações que lhes são confidenciadas pelos vários envolvidos, não constituem um grupo em si. A maior parte sequer sabe nomear mais do que meia dúzia de colegas com quem trabalham na Rocinha diariamente. Serão, talvez, a pesquisadora e sua equipe? Longe disso! A bem da verdade, jamais deixamos de nos surpreender com a intensidade e a velocidade com o que o campo da favela turística continuamente se renova. Uma dessas surpresas ficou por conta da revelação de que a maior parte dos moradores desconhecia o fato de as agências cobrarem pelos passeios à Rocinha $(76 \%$ dos entrevistados). Mesmo os que sabiam que se tratava de uma visita paga, raramente tinham ideia de quanto era cobrado. Nós, pesquisadores, nos vimos na situação de ter que interferir na realidade pesquisada, revelando aos entrevistados a quantia cobrada aos turistas, ao que muitos reagiram com indignação: "Ah, é assim?! Eu também queria ter um emprego desses..." Outros propunham um valor completamente inflacionado: "Acho que eu cobraria bem. Assim, uns $\mathrm{R} \$ 500,00$ de cada um... Isso que elas [as agências] cobram é pouco."

No entanto, $70 \%$ dos entrevistados responderam que não receberia nada pelo passeio. "Não, não sou de cobrar a ninguém", respondeu I., empregada doméstica de 49 anos. E justificou: "É algo que se faz por amor e o amor não tem preço. Faria o passeio com todo gosto, levaria para passear, para conhecer a Rocinha, faria com o maior prazer." M., de 28 anos, que trabalha como forneiro, concorda: "Eu não cobraria nada. Faria na maior boa vontade, sem cobrar nada. Os turistas [mexicanos] que vieram para cá uma vez 
me ofereceram dinheiro e eu disse 'não quero, não quero'. E eu fiquei 'amarradão' dos caras conhecerem a comunidade onde eu fui criado, onde eu vivo... As agências cobram? Eu não sei... Então eu não posso dizer se está caro, se está barato. Eles devem ter os gastos deles também. Eu faria de graça, sem cobrar nada."

Todas as vezes que nossa equipe participou dos tours, crianças e adultos foram extremamente receptivos aos turistas, acenando com entusiasmo e arriscando algumas palavras em inglês. Obviamente, não estamos negando a relação de iniquidade entre os turistas do Primeiro Mundo e os moradores, mas é importante perceber que os favelados não são elementos passivos do olhar curioso do visitante. Como me disse o motobói H., "morador não é otário, a gente está ligado na intenção de vocês [pesquisadores? gringos? guias? visitantes em geral?], a gente sabe que a galera vem aqui para se divertir, mas também para ver o barraquinho, para ver o bandidão."

Como bem observa o sociólogo Georg Simmel (1964), as ações recíprocas não implicam simetria dos atores em seu poder de interagir. Dito de outro modo, a reciprocidade está presente nas interações as mais desiguais, mesmo nas relações que parecem ser exclusivas e altamente hierárquicas. Tomando como referência a troca de olhares, Simmel defende a ideia de que as interações são a um só tempo ativas e passivas:

O olhar pelo qual procuramos perceber o outro é em si mesmo expressivo... O ato pelo qual o observador procura conhecer a pessoa que ele observa é uma capitulação através da qual ele próprio aceita ser observado. $\mathrm{O}$ olho não pode tomar sem ofertar ao mesmo tempo (apud Joseph, 1998: 19).

Nos passeios que acompanhamos, pudemos presenciar como os turistas tornam-se também uma divertida e exótica atração para os moradores. Adultos e crianças fazem comentários jocosos sobre as roupas e os cabelos dos visitantes: "Olha lá o modelito dele!"; "Essa daí está pronta para o safari." Um turista loiro é saudado com um "Fala aí, David Beckham!", enquanto uma jovem indiana é apelidada de Beyoncé. "Eu fico zoando porque eu não sei falar a língua deles", justifica uma garotinha de 11 anos. Outras tantas vezes, aos turistas são atribuídas qualidades infantis: "Eles têm a linguinha enroladinha, uma graça!"; "Eu adoro ver quando eles passam em dia de chuva, com aquelas capinhas amarelas, tudo parecendo uns pintinhos." 0 olhar que estranha, no mais das vezes, é devolvido à presença estrangeira 
que, de tão frequente, passa a ganhar um estatuto de quase normalidade. Ao the perguntarmos desde quando começara a perceber a presença de turistas na favela, uma moradora respondeu: “Ah, faz tempo, quase dez anos. Eles passam livremente pelas ruas, andam pelos becos, no meio de nós, como se fossem pessoas normais."

Posturas percebidas como intrusivas, muitas vezes são revidadas com veemência, como nos relatou uma guia turística que atuou durante muitos anos exclusivamente nos tours de favela: "O turismo na favela é um pouco invasivo sim, sabe? Porque você anda naquelas ruelas apertadas e as pessoas deixam as janelas abertas... E tem turista que não tem 'desconfiômetro', mete o carão dentro da casa das pessoas! Isso é realmente desagradável. Já aconteceu não comigo, mas com outra guia... A moradora estava cozinhando e o fogão dela era do lado da janelinha; o turista passou, meteu a mão pela janela e abriu a tampa da panela. Ela ficou uma fera! Aí fez assim [bateu na mão dele]!"

As ações mal-educadas dos turistas não precisam ser tão explícitas quanto no caso narrado acima para provocar reações de crítica e desconforto por parte dos moradores. Em um dos passeios que acompanhei, uma turista, ao atravessar uma das inúmeras vielas em que o esgoto corre a céu aberto, tampou o nariz. Duas moradoras que conversavam à porta da casa fizeram questão de mostrar sua censura ao comportamento da turista, balançando a cabeça em negativa. A visitante, constrangida, sussurrou um "sorry" que não passou inaudível às moradoras.

Zigmunt Bauman (1993) argumenta que o cheiro é essencialmente subversivo: como não pode ser banido, revela a artificialidade da Modernidade e de seu grande projeto de criar uma ordem pura e racional. Um cheiro ruim, como o identificado pela turista, nos faz lembrar que o mundo não pode ser totalmente controlado, assim como nossas reações espontâneas ao que considera ofensivo o nariz acostumado aos espaços asseptizados dos shoppingcenters. É interessante notar que são pouquíssimos os relatos produzidos pelos turistas que fazem referência ao cheiro da favela, em um contraste significativo com a profusão de imagens visuais do lixo e das valas. Nesse sentido, cabe lembrar o que Walter Benjamin, ainda em inícios da década de 1930, apontava: a fotografia, ao registrar a pobreza abjeta de acordo com a voga, é capaz de convertê-la em um objeto de apreciação. Mas se a apreensão visual por meio da fotografia permite um redirecionamento estético das imagens da pobreza, o mesmo não se dá com os seus odores. O cheiro da vala, 
do esgoto a céu aberto, do lixo exposto ao sol não se prestam tão facilmente a essa estetização, não podem ser domado - ou se fala deles ou se silencia.

S. tinha 18 anos à época da pesquisa e fora morar na parte baixa da Rocinha ainda adolescente. Já trabalhara como balconista, mas estava desempregada no momento da entrevista: "Eu vejo turistas desde que eu cheguei aqui na Rocinha... Eu acho que para o guia eles devem trazer alguma coisa [de bom], mas para a gente, não. Ontem mesmo... a moto em que eu estava ia batendo porque eles [os turistas] pararam na nossa frente e ficaram lá, estacionados. Então engarrafa, faz um monte de coisas quando o carro deles [das agências] fica parado no meio do caminho. Ninguém fala nada porque a gente acha que traz alguma coisa para a gente aqui. Eles compram besteira, tipo feirinha, cordão, mas acho que nunca doaram nada para a gente aqui não... Eu acho que não, não é maneiro não. Porque eles só ficam tirando foto de coisas que não tem nada a ver. Eu já vi um tirando foto de uma lixeira. Já vi outro tirando foto de um barraco que tem lá para cima no Cesário... Às vezes é até bom, tudo bem, porque o lugar que a gente mora é visitado, mas também é um pouco chato. A gente fica até com vergonha porque eles vão mostrar lá no país deles que a Rocinha é suja, é nojenta, sei lá?" Quando perguntamos por que os turistas têm interesse em visitar a Rocinha, S. reagiu com indignação: "Ahhh, é isso que eu me pergunto!!! O Rio de Janeiro tão bonito, tanto lugar para eles irem, tanto lugar... Por que eles vêm justo pra Rocinha, uma favela, uma comunidade? Gente, está na cara que é para sair falando! Acho que mal, né? Porque nada a ver!!!"

Desconfiar das intenções dos turistas ou se aborrecer com determinados comportamentos não significa, necessariamente, Ihes ser hostil. "Eles já me fotografaram", lembra sorrindo. "Uma vez, eu e minha colega, a gente estava abraçadas, a gente mandou tchau para eles e eles perguntaram se podiam fotografar. Aí a gente mandou beijo e eles fotografaram!"

Assim como S. a maior parte dos moradores com os quais conversamos diz não se incomodar com as câmeras estrangeiras. Os poucos que não gostam das fotos justificaram uma timidez ou vergonha relacionada ao fato de ser fotografado em qualquer situação e não um desconforto diante do turista. Há queixas específicas, como a de morador que um dia, ao navegar pela Internet, deparou-se com uma foto sua em um fotolog de um turista que não Ihe havia pedido autorização. Mas a maioria afirmou se sentir valorizada por ser alvo das lentes e ter sua imagem sorridente circulando mundo afora. Apreciam ainda mais quando recebem, por intermédio das agências, 
cópia das fotos que os turistas tiraram deles - o que costuma ser uma prática mais recorrente do que esperávamos.

"Se até então boa parte da população de favelas não se reconhecia na representação que circula pela mídia dos 'favelados' como atores sociais frequentemente associados à violência armada"'- sugere Menezes (2007) "agora vários dos moradores passam a se reconhecer nessas novas imagens produzidas pelos turistas." Incomoda, porém, o fato de ser o contato intermediado pela câmera uma das poucas formas de interação durante os passeios e que certos estereótipos estejam sendo reforçados. Pensemos, por exemplo, no fato de a maioria das pessoas fotografadas serem negras quando, na verdade, o leque de tipos físicos é extremamente variado na Rocinha. Esse dado leva Menezes (2007) a sugerir que os turistas talvez prefiram fotografar pessoas que se enquadrem no estereótipo "favelado é preto e pobre." "Uma vez, quando meu filho era mais novo, [alguns turistas] quiseram tirar foto dele, mas quando eu cheguei com ele [que é branco], eles não quiseram, porque eles queriam um neguinho."

\section{Conclusão}

Daniela Schilcher (2007), em um balanço crítico da prática do chamado propoor tourism em diferentes partes do mundo, argumenta que há um paradoxo próprio ao turismo em áreas pobres: por um lado, trata-se de uma atividade que, ao ressaltar a potencialidade de exploração de "inesperados" e novos atrativos, combina bem com interpretações neoliberais do alívio à pobreza; por outro, quando num ambiente de livre mercado, o turismo tende justamente a agravar as desigualdades que reforçam a pobreza nesses territórios. A partir de dados de pesquisas atuais sobre o combate à pobreza, Schilcher defende que, para ser de fato "pró-pobre", as práticas turísticas teriam de conferir benefícios desproporcionais aos mais carentes. A autora conclui que estratégias para reforçar a igualdade por meio do repasse de benefícios aos pobres pela via do turismo dificilmente serão levadas adiante devido a limitações próprias à ideologia neoliberal e à "ortodoxia do Banco Mundial". Abordagens mais radicais, como a regulamentação e distribuição dos lucros gerados com o turismo, estão fadadas a permanecer predominante retóricas.

Schilcher (2007) tem razão quando identifica grande afinidade entre o turismo e a ideologia neoliberal, pois as práticas turísticas tendem a florescer em 
ambientes econômicos abertos que facilitam a livre movimentação de capital, trabalho e consumidores. De fato, como nos diz Néstor Canclini (2003), o neoliberalismo celebra toda a diferença que é capaz de mercantilizar, de tornar palatável ao gosto do consumidor. É próprio da lógica neoliberal fazer da diferença um "festival exótico" (o que significa reconhecer geralmente o sujeito dessa diferença como objeto) e não há dúvidas de que o turismo fornece uma excelente oportunidade para esse tipo de encenação.

A autora pode estar equivocada, porém, quando sugere como saída para os males do turismo de pobreza "instituições fortes, capazes de regular a indústria do turismo e distribuir bens" (Schilcher, 2007: 38). Vemos que, no caso da favela turística, os dramas vividos entre vários atores sociais presentes na cena ultrapassam, em muito, questões que podem ser simplesmente deliberadas por uma ou mais instâncias superiores e supostamente neutras. As interações sociais encenadas na favela turística não podem ser explicadas se referidas apenas a categorias abstratas como "pobre", "turista", "agência de turismo", "poder público", "capital". A complexidade dos dilemas e expectativas que a favela turística encerra aparece com nitidez na fala de um morador da Rocinha entrevistado por Menezes (2007): "Acho que os turistas deveriam visitar os lugares mais pobres e mais sujos da favela, porque às vezes eles só passam pelos lugares mais ricos, mais bonitos e até mais limpos. Mas se eles fossem lá para a Roupa Suja, onde o pessoal é mais necessitado, talvez eles pudessem se inspirar em limpar o lugar, talvez alguém se interessasse em ajudar mais os moradores... Alguém poderia trazer dinheiro, consertar um cano. Isso iria beneficiar a galera lá, porque ia incentivar os moradores a consertar as casas, tirar a lama, tirar o lixo. O poder público ia olhar mais para aquela gente. O passeio não seria só para mostrar a vista, mas para mostrar a realidade."

$\mathrm{Na}$ fala do morador, se coloca um encadeamento de responsabilidades entre turistas, moradores das áreas mais pobres e poder público. Esse encadeamento, provocado pelo turismo, supõe que visitantes inspirados pela visão da pobreza degradante partiriam para uma ação que beneficiaria o local; que moradores, percebendo a presença dos turistas, passariam a cuidar melhor de suas casas e do entorno; que o poder público, incentivado pelas ações de turistas e moradores, passaria a prestar a atenção devida à localidade. A questão do morador não é se o turismo na favela deve ou não existir, mas sim como os passeios devem ser conduzidos e que comportamentos deveriam ser motivados. Descobrimos, então, que se trata, de fato, de um contínuo, e não de uma dicotomia organizada em polos distantes. 
Moradores, turistas, guias, pesquisadores e outros mais estamos todos constantemente negociando e renegociando uma nova gramática cuja pretensão é acomodar, no território da favela turística, lazer e pobreza, diversão e comiseração.

Em diferentes oportunidades, Simmel (1964) insistiu na ideia de que a sociedade "como tal" era uma ilusão acionada para dar conta de um movimento contínuo de indivíduos que vivem para o outro, com o outro ou contra o outro. Parafraseando Simmel, poderíamos dizer que não há favela turística "como tal", mas dinâmicas de aproximação e afastamento entre diferentes atores sociais cujas identidades - "favelado", "guia", "gringo" - não são apenas identidades que os atores sociais trazem para a favela turística, mas identidades que são construídas por meio da favela turística. Estas identidades são constituídas, observadas e julgadas, não apenas exibidas. Todos têm uma opinião sobre as atitudes dos demais, ainda que sejam opiniões contraditórias e baseadas em idealizações. Turistas idealizam os favelados, que podem ser vistos como "guardiões" dos valores autênticos e do que "realmente importa", mas também como "coitados" e "miseráveis"; moradores idealizam os turistas, considerados ao mesmo tempo "generosos" e "solidários", mas também "rudes" e "sem noção"; agências idealizam tanto turistas quanto moradores e, com base nessas idealizações, traçam seus roteiros, respondem a demandas e muitas vezes precisam intermediar conflitos. Todos procuram, cada um a partir do lugar que ocupa, criar regras de interação, provocando a formulação coletiva de uma gramática de sociabilidades que é cotidianamente atualizada. Constrangimentos, mal-entendidos, conflitos e disputas vão, à medida mesmo em que acontecem, sendo incorporados à tal gramática de interações ou como nova regra ou como exceção a regras existentes.

Quer se goste ou não, o fato é que a Rocinha turística é um negócio rentável para as agências de turismo envolvidas, um destino cobiçado pelos estrangeiros e uma realidade cotidiana para seus moradores.

Abstract: Rocinha is the paradigmatic touristic favela, with tours taking place regularly since the early 1990s and with 3,500 tourists visiting the site each month. What do the inhabitants of Rocinha think about these tourists and their cameras? Do they perceive this presence as something that humiliates and objectifies them or as a possibility of empowerment? The methodology included different strategies: field observation, participant observation in different tours, long interviews with qualified informants and semi- 
structured interviews with 175 inhabitants from Rocinha. The article concludes that between the total approval of and unconditional disagreement towards the touristic practices, there are some nuances which should be carefully examined.

Keywords: Tourism; favela; favelados; poverty; Rio de Janeiro.

\section{Bibliografia}

Barretto, M. (2003) "O imprescindível aporte das ciências sociais para o planejamento e a compreensão do turismo", Horizontes Antropológicos, 9(20). Porto Alegre: Editora UFRGS.

BAUMAn, Z. (1993) Modernity and ambivalence. Oxford: Blackwell.

___ . (2001) Community: Seeking safety in an insecure world. Cambridge: Polity.

Benjamin, W. (1994) "Pequena história da fotografia", in idem [1931], Obras escolhidas. Magia e técnica, arte e política. São Paulo: Brasiliense.

CAncLINI, N. G. (2003) A globalização imaginada. São Paulo: Iluminuras.

Carter, J. (2005) "An outsider's view of Rocinha and its people". M. A. Dissertation, University of Texas at Austin.

DWEK, D. (2004) "Favela tourism: Innocent fascination or inevitable exploitation?" M. A. Dissertation, University of Leeds.

Freire-Medeiros, B. (2007) "A favela que se vê e que se vende: Reflexões e polêmicas em torno de um destino turístico". Revista Brasileira de Ciências Sociais, 22: 61-72.

-—— . (2009) Gringo na laje: Produção, circulação e consumo da favela turística. Rio de Janeiro: Editora FGV.

—_- et alii. (2008) "Ética, estética e consumos possíveis: Notas etnográficas sobre turismo em uma favela carioca". Os Urbanitas, Vol. 5, n. 3.

Freire-Medeiros, B; Menezes, P. \& Nunes, F. (2008a) "Ética, estética e consumos possíveis: Notas etnográficas sobre turismo em uma favela carioca". Os Urbanistas, Vol. 5 , n. 7. 
Joseph, I. (1998) Erving Goffman et la microsociologie. Paris: Presses Universitaires de France.

Leite, M. P. (2008) "Para além da metáfora da guerra: violência, cidadania, religião e ação coletiva no Rio de Janeiro". São Paulo: Attar Editorial/CNPqPronex Movimentos Religiosos no Mundo Contemporâneo.

MaCHADO, D. S. (2007) "Turismo de favela e desenvolvimento sustentável: Um estudo do turismo de favela no bairro de Vila Canoa, zona sul do Rio de Janeiro". Dissertação de mestrado, Rio de Janeiro: PUC-RJ .

Menezes, P. (2007) "Gringos e câmeras na favela da Rocinha". Monografia de bacharelado, Rio de Janeiro, Universidade do Estado do Rio de Janeiro (Uerj).

SCHILCHER, D. (2007) "Growth versus equity: The continuum of pro-poor tourism and neoliberal governance", Current Issues in Tourism, Vol. 10, Issue 2 \& 3. Londres/Nova York: Routledge.

Simmel, G. (1964) The Sociology of Georg Simmel (edição K. H. Wolff). Nova York: The Free Press.

URRY, J. (2007) Mobilities. Cambridge: Polity.

Valladares, L. (2005) A invenção da favela: do mito de origem a favela.com. Rio de Janeiro: FGV Editora.

Zelizer, V. (2005) The purchase of intimacy. Princeton/Oxford: Princeton University Press. 